HBe 抗原陽性慢性肝疾患患者の southern blot-hybridization に

\title{
よる肝内 HBV-DNA の解析
}

\begin{tabular}{llll} 
今関 文夫 & 小俣 & 政男 & \multicolumn{2}{l}{ 横須賀 収 } \\
伊藤よしみ & 内海 & 勝夫 & 森 順子 \\
松山 泰久 & 奥田 & 邦雄* &
\end{tabular}

要 旨: $\mathrm{HBe}$ 抗原陽性慢性肝疾患患者15例の肝生検材料（一部剖検材料）を用い, Southern blot 法及び cloned HBV-DNA probeにより，肝細胞内 hepatitis B virus DNA (HBV-DNA) の存在様式の検討を行なった。 全例に free HBV-DNA がみられ，3 種類以上の HBV-DNA の バンドは肝内における異なる増殖過程を示すむのと思われた．肝細胞 DNAへの HBV-DNA の integrationは，慢性持続性肝炎，慢性活動性肝炎には認められなかったが，進行した高龄の 肝硬変の 2 症例にみられた。

肝細胞 DNA への HBV-DNAの integration が，肝癌の高危険群と考えられる，高龄でしか も進行した肝硬変症例に打いて認められたことは興味深い.

索引用語： HBe 抗原陽性慢性肝疾患 southern blot-hybridization cloned HBVDNA probe free HBV-DNA integrated HBV-DNA

\section{緒 言}

最近, 肝癌細胞の DNA 中に hepatitis B virus DNA (HBV-DNA) が高頻度に組又込まれている事実 ${ }^{1-3)}$ が 明らかにされ，疫学的な裹づけ4と共に，発癌に HBVDNA が何らかの役割をはたしている可能性が強く示 唆されている。しかしながら非癌肝疾患における肝内 HBV-DNAの検索は未だ十分にされていない。

また近年, $\mathrm{HBe}$ 抗原陽性慢性肝疾患に対して, Adenine arabinoside, InterferonあるいはSteroid の 離脱療法等による積極的な治療が試みられ, 病変の進 行をおさ方努力がなされているが，治療の適応，あ るいは治療効果を検討する上で, HBe 抗原陽性慢性肝 疾患の肝内に批ける HBV-DNAの存在様式を解析す ることは有意義と考えられる。

\section{対象及U大方法}

Radioimmunoassay 法にて $\mathrm{HBe}$ 抗原陽性が確認さ れた慢性肝疾患患者 15例 (Table 1) の肝生検材料 (症 例 1 13，15) 及び剖検材料（症例14）を対象とした。 その組織診断は, Table 1 亿示す如く，慢性持続性肝 炎 $(\mathrm{CPH}) 7$ 例, 慢性活動性肝炎 $(\mathrm{CAH}) 5$ 例, 肝硬 変 3 例であった。

\footnotetext{
*千葉大学医学部第一内科
}

Table 1. Histological findings and viral nucleic acid study by HBV.DNA blot hybridization.

\begin{tabular}{|c|c|c|c|c|c|c|}
\hline \multirow{2}{*}{ Patient } & \multirow{2}{*}{ Age } & \multirow{2}{*}{ Sex } & \multirow{2}{*}{$\mathrm{HBeAg}$} & \multirow{2}{*}{ Histology } & \multicolumn{2}{|c|}{ HBV-DNA } \\
\hline & & & & & Free & Integrated \\
\hline 1. & 32 & $\mathrm{M}$ & Pos. & $\mathrm{CPH}$ & $H$ & - \\
\hline 2. & 38 & $\mathrm{~F}$ & Pos. & $\mathrm{CPH}$ & $H$ & - \\
\hline 3. & 25 & $\mathbf{M}$ & Pos. & $\mathrm{CPH}$ & H & - \\
\hline 4. & 35 & $\mathbf{M}$ & Pos. & $\mathrm{CPH}$ & H & - \\
\hline 5. & 23 & M & Pos. & $\mathrm{CPH}$ & + & - \\
\hline 6. & 35 & F & Pos. & $\mathrm{CPH}$ & $H$ & - \\
\hline 7. & 24 & M & Pos. & $\mathrm{CPH}$ & + & - \\
\hline 8. & 33 & $\mathbf{M}$ & Pos. & $\mathrm{CAH}$ & H & - \\
\hline 9. & 35 & M & Pos. & $\mathrm{CAH}$ & H & - \\
\hline 10. & 46 & $\mathbf{M}$ & Pos. & $\mathrm{CAH}$ & H & - \\
\hline 11. & 21 & $\mathrm{~F}$ & Pos. & $\mathrm{CAH}$ & + & - \\
\hline 12 . & 29 & $\mathbf{M}$ & Pos. & $\mathrm{CAH}$ & + & - \\
\hline 13. & 27 & $\mathbf{M}$ & Pos. & $\begin{array}{c}\text { CAH \& } \\
\text { Cirrhosis } \\
\text { (Early) }\end{array}$ & H & - \\
\hline 14. & 60 & $\mathrm{~F}$ & Pos. & $\begin{array}{l}\text { Cirrhosis } \\
\text { (Advanced) }\end{array}$ & $H$ & + \\
\hline 15. & 70 & $\mathbf{M}$ & Pos. & $\begin{array}{l}\text { Cirrhosis } \\
\text { (Advanced) }\end{array}$ & $H$ & + \\
\hline
\end{tabular}

Tru-Cut 針にて， 2 回穿刺施行，一本は $10 \%$ ホルマ リン固定, バラフィン包埋後, へマトキシリンーェオ シン染色等により組織学的診断に供した。もら一本は, 
急速に $-80^{\circ} \mathrm{C}$ 凍結保存し DNA の解析に用いた，肝生 検材料は4 29mg, 平均 $16 \mathrm{mg}$ であった.

凍結肝缄は, $0.5 \mathrm{~m} l$ の $10 \mathrm{mM}$ Tris- $\mathrm{HCl}(\mathrm{pH} \mathrm{7.4)}$ $10 \mathrm{mM}$ EDTA 溶液中にてダゥンスホモジナイザーで ホモジナイズした後, さらに同量の $200 \mathrm{mM} \mathrm{NaCl}, 20$ $\mathrm{mM}$ Tris- $\mathrm{HCl}$ (pH 7.4), 2mM EDTA, $1 \mathrm{mg} / \mathrm{m} l$ Pronase (Calbiochem-Behring Corp., 77,000RUK/ gm), 1\% SDS を加え, $37^{\circ} \mathrm{C}$ で30分間反応後, フェノー ルークロロホルム（1：1）で2回抽出した．更に 2 倍量 の $100 \%$ ×タールを加立, $-20^{\circ} \mathrm{C}$ に30分放置, 沈渣を $100 \%$ タノールで 3 回洗浄後，乾燥し， $5 \mathrm{mM}$ Tris$\mathrm{HCl}(\mathrm{pH} 7.4)$, 1mM EDTAに溶解, 使用まで $4^{\circ} \mathrm{C} に$ 保存した. 肝 DNA の収量は, 約 $3 \sim 4 \mu \mathrm{g} / \mathrm{mg}$ であっ た.

肝抽出 DNA 約 $10 \mu \mathrm{g}$ を用い，全例，制限䣼素 EcoRl (BRL, 10units $/ \mu l$ ) 及び Hind III (BRL, 10units $/ \mu l$ ) にて消化し，水平スラブゲル（1.5\%アガロースゲル） にて20mA，10時間泳動後, Southern blot 法5)にて nitrocellulose filter 紙に移行させた.pBR322にクロー ン化された HBV-DNA（J.Summers 博士提供）を, 32 P.dCTP (Amersham, $410 \mathrm{Ci} / \mathrm{mmol}$ ) を用い, nick translation 法6)にて probe 作製し, hybridization 施 行, コダックX-OMAT・XAR-5を用い, $-80^{\circ} \mathrm{C} に て$ autoradiography を行ない梌索した, phage lambda DNA を Hind III で消化し，DNA サイズの指標とし て用いた, probe の specific activity は1 $2 \times 10^{8} \mathrm{cpm} /$ $\mu g$ DNA であった.

\section{成 緽}

Table 1 k示す HBe 抗原陽性慢性肝疾患患者15例 すべての肝抽出 DNA K free HBV-DNA が認められ た.

Fig. 1 の Lane 1, 2, 3は各々, 症例 6，8，7に相 当し，これらの症例は，35歳，33歳，24歳の三兄弟で あり, 母親は HBs 抗原陽性肝細胞癌にて既に死亡し ている.この 3 例とも，母親からの垂直感染により $\mathrm{HBV}$ キャリフ化したと考えられ，今回の検索では肝 細胞 DNA への HBV-DNA の integrationは認めら れなかったが, 今後の推移を慎重に見守る必要がある.

Fig. 2 は, Lane 1 3か症例 No. 10, Lane 4 6が No. 2であり，Lane 1,4は未消化，Lane 2,5は EcoRI で，Lane 3，6は Hind IIIで消化したものであり，肝 細胞 DNA への integrationは認められなかった。 Lane 1ではa, b, cのパンドがみられ, Fig. 3 の Lane 1は同じサンブルを解析したすのであるが, 約4kbのパ

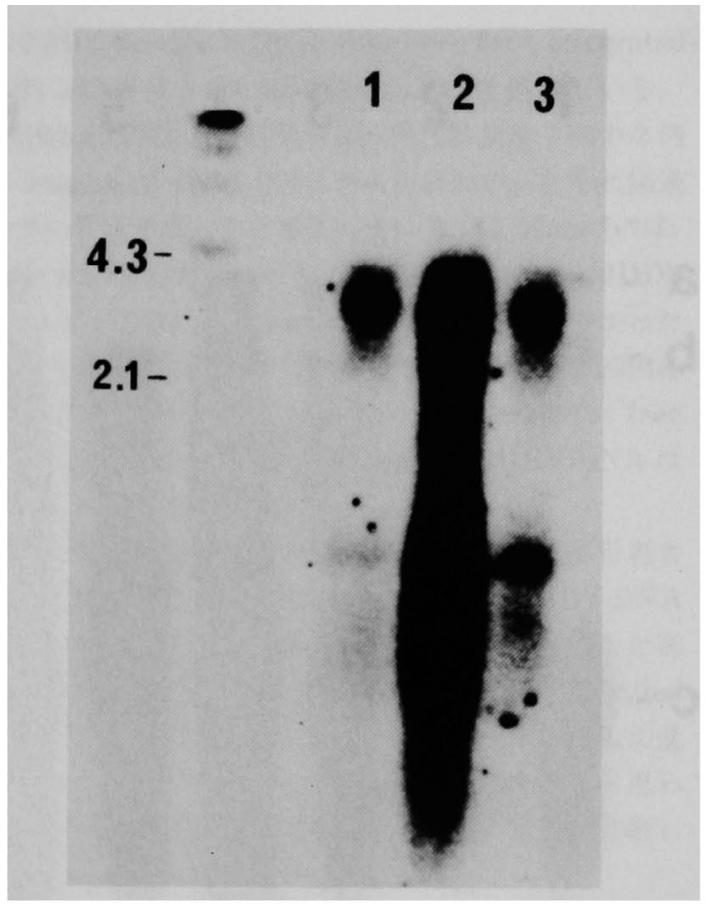

Fig. 1 HBV.DNA hybridization analysis of DNA extracts from liver tissue of three siblings with $\mathrm{HBeAg}$ positive chronic liver disease. Lane 1; liver DNA from Patient $6(6 \mu \mathrm{g})$, undigested. Lane 2; liver DNA from Patient $8(17 \mu \mathrm{g})$, undigested. Lane 3 ; liver DNA from Patient 7 (15 $\mu \mathrm{g}$ ), undigested.

ンド a は relaxed circular double-stranded HBVDNA，約3.2kbのバンドbは liner double-stranded HBV-DNA, バントC及びそれより小さなサイズのス メアー状に認められるるのは, $100^{\circ} \mathrm{C} 3$ 分間熱処理によ $り$ 単鎖化したDNAの泳動部位と一致し, singlestranded HBV-DNA と考えられた。尚, バンドbとc の間にるハンドが認められ, supercoiled closed circular double-stranded HBV-DNA に相当するものと考 えられた。尚, 制限醇素 Hind III は HBV-DNAK cutting site を持たないので, free HBV-DNA は泳動 パターンに影䉡をらけないか， EcoRl は cutting site を 1 つ持つ為, Fig. 2 Lane 5に見られる如く，バンド a はbに, バンドbは更に小さなサイズに移動してい る.

Fig. 4 は, No. 14の肝硬変症例の肝内 HBV-DNA を検索したものである. Lane 3が未消化，1，2がそ れぞれ Hind III 及びEcoRlで処理したもので, free HBV-DNA の存在とともに, Lane 1では4kbより大き 


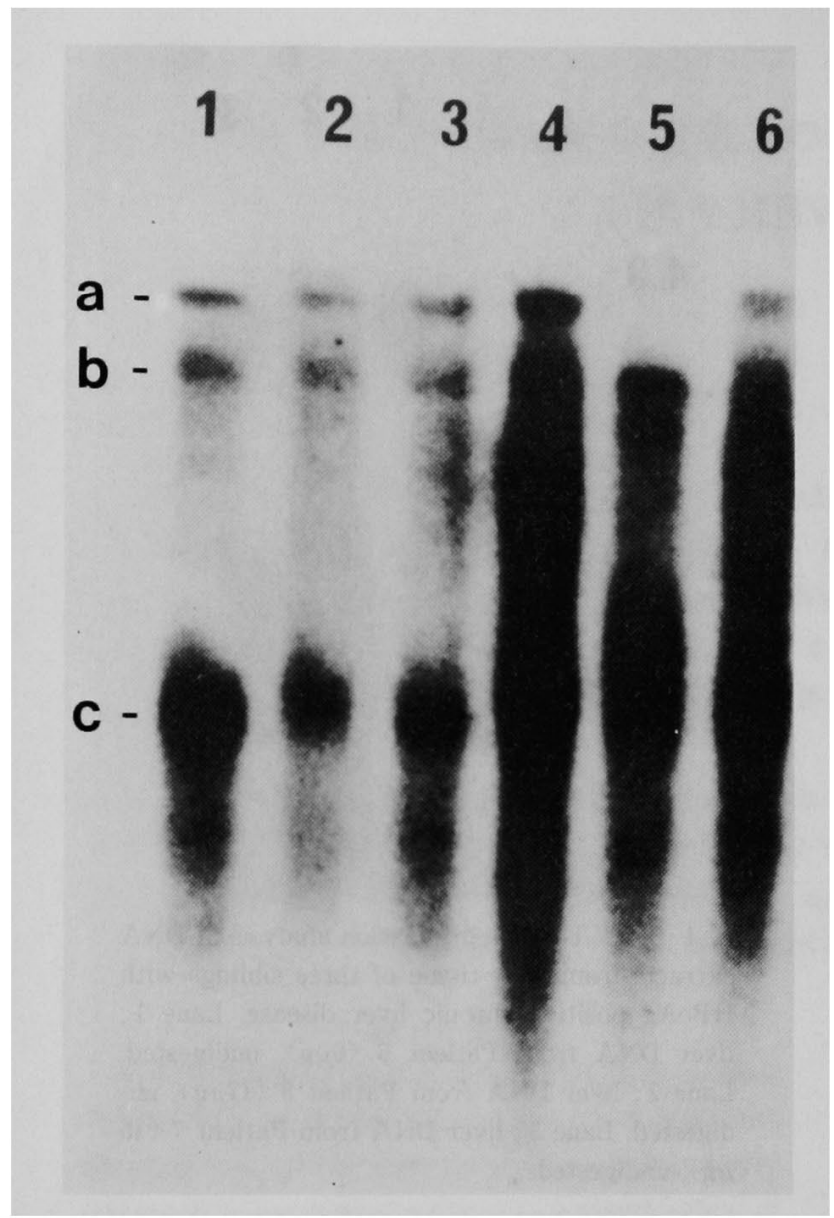

Fig. 2 HBV-DNA hybridization analysis of DNA extracts from liver tissue of 2 patients with HBeAg positive chronic hepatitis. Lane 1; DNA from Patient $10(10 \mu \mathrm{g})$, undigested. Lane 2; DNA from Patient $10(10 \mu \mathrm{g})$, digested with EcoRl. Lane 3 ; DNA from Patient $10(10 \mu \mathrm{g})$, digested with Hind III. Lane 4 ; DNA from Patient $2(10 \mu \mathrm{g})$, undigested. Lane 5 ; DNA from Patient $2(9 \mu \mathrm{g})$, digested with EcoRI. Lane 6; DNA from Patient $2(9 \mu \mathrm{g})$, digested with Hind III. a), b), and c) on the left side of autoradiogram ; identification of major bands.

なサイズのバンドが羿められ，肝細胞 DNAへ HBVDNA が組み込まれていると考えられる。ささらに, No. 15に扎いても肝細胞 DNA へ HBV.DNAの integrationがみられた。

非癌慢性疾患における HBV-DNA の組み込みのパ ターンは，報告7 99により必ずしも一定ではなく，今回 我々の検索において, Fig. 4 の Lane 3では $4 \mathrm{~kb}$ 上り高

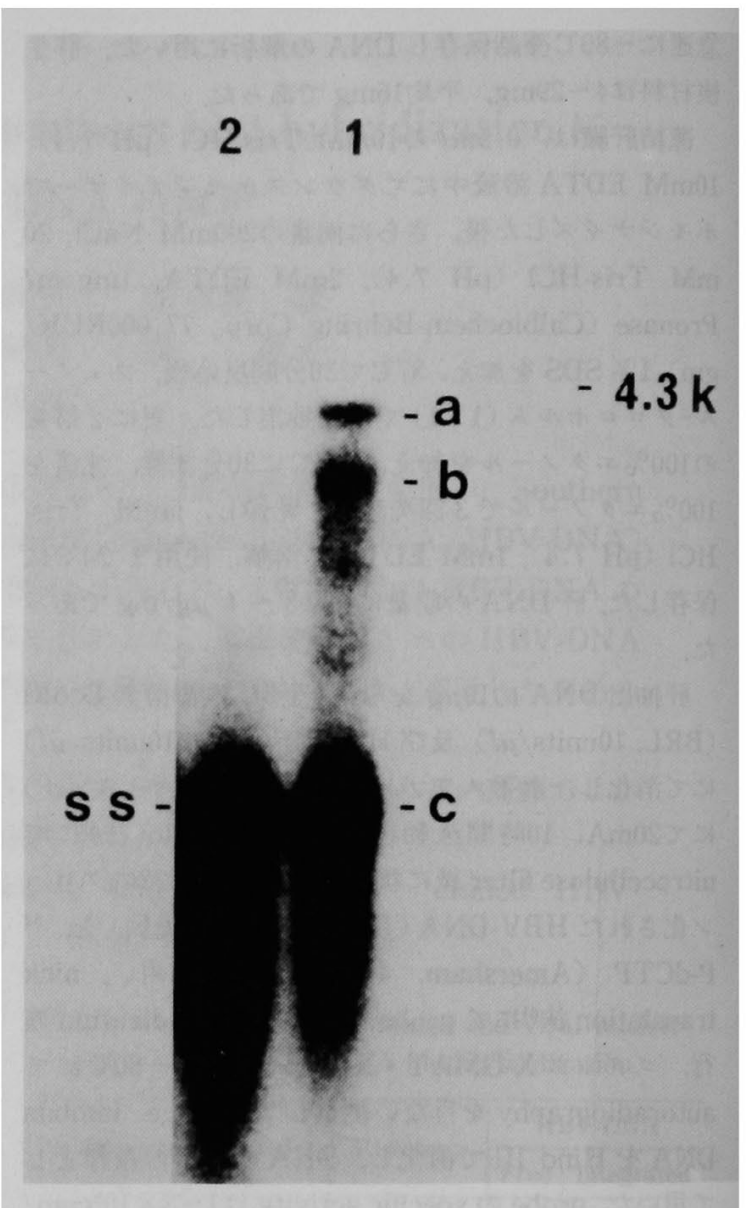

Fig. 3 HBV-DNA hybridization analysis of DNA extracts from liver tissue of Patient 10 with HBeAg positive chronic active hepatitis. Lane 1; undigested $(10 \mu \mathrm{g})$. Lane 2 ; preheated at $100^{\circ} \mathrm{C}$ for $3 \mathrm{~min} .(20 \mu \mathrm{g}) . \mathrm{a}), \mathrm{b})$, and $\mathrm{c}$ ) on the right side of autoradiogram; identification of major bands. ss; single-stranded HBV-DNA.

位にはっきりしたバンドは認められていないが, autoradiography の時間をさらに長くすることによ ク，スメアー状に確認されており，制限醉素 Hind III 処理で4kbより高位にバンドが生じていることより， HBV-DNA の肝細胞 DNA への integration が考えら れる.

Fig. 5 は, No. 15 の肝組織像で, 大小の倄小葉より なる完成された肝硬変である。このように結節を形成 した肝細胞は，より均一な細胞集団からなっていると 考克られる。

以上より， $\mathrm{CPH}$ 及び $\mathrm{CAH}$ (平均年齢 31.3 歳) の 12 


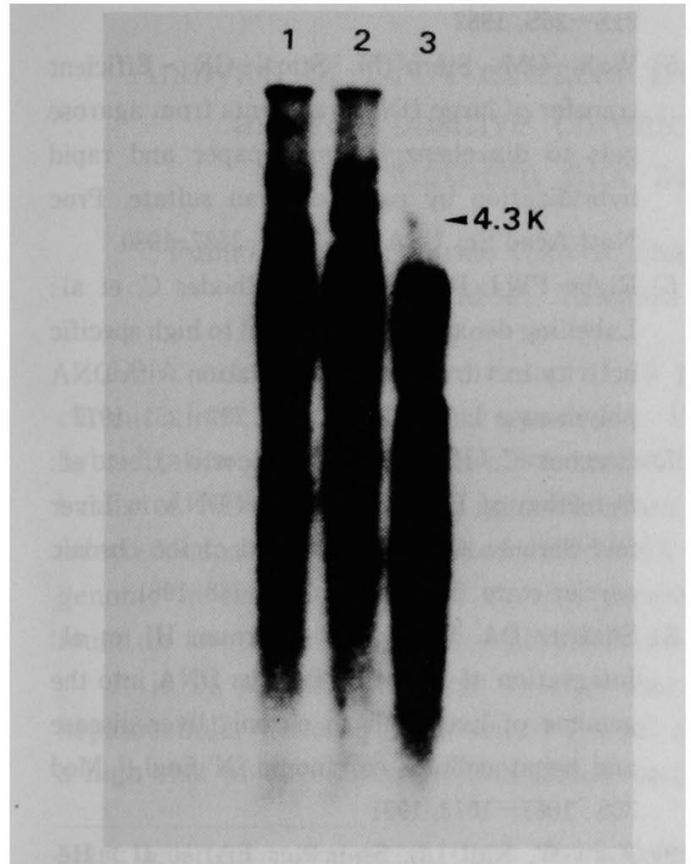

Fig. 4 HBV-DNA hybridization analysis of DNA extracts from liver tissue of Patient 14 with $\mathrm{HBeAg}$ positive liver cirrhosis. Lane 1 ; digested with Hind III $(10 \mu \mathrm{g})$. Lane 2 ; digested with EcoRl $(10 \mu \mathrm{g})$. Lane 3 ; undigested $(11 \mu \mathrm{g})$.

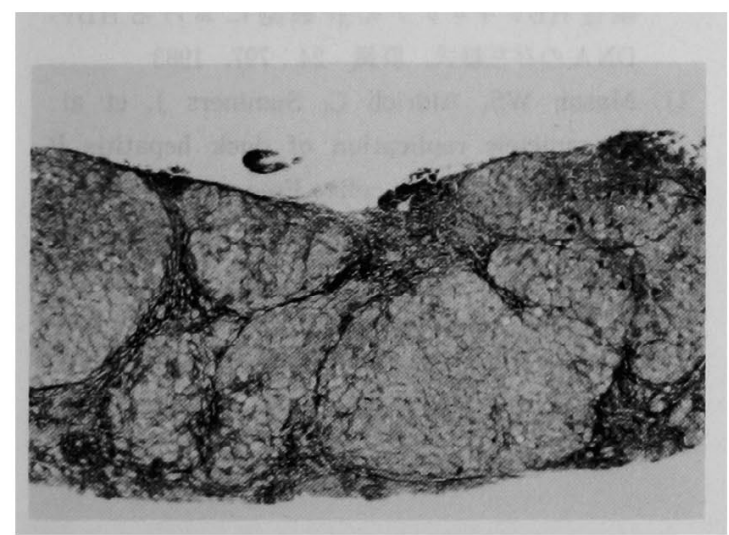

Fig. 5 Photomicrograph of liver biopsy specimen from Patient 15 with $\mathrm{HBeAg}$ positive cirrhosis (Mallory-Azan stain, $\times 40$ ).

例においては integrated HBV-DNA は見い出されな かった。一方, 旰硬変症 3 例中60歳及び70歳の高龄で, しかも進行した肝硬変症の 2 例に組み込まれた HBV. DNAが見い出された。

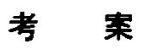

Brechot ら"1は, HBe 抗原陽性慢性肝疾患15例の5
ち全例に free HBV-DNA がみつかったが, integrated HBV-DNA 1 1 例にのみ認められたと述べている。 Shafritz $5^{8)}$ は, HBs 抗原陽性慢性肝疾患 7 例中 2 例 に integrated HBV-DNAがみられたが，ともに経過 の長い症例であったと報告している. 又, Kam らは， $\mathrm{HBe}$ 抗原陽性 $\mathrm{HBV} キ+リ>4$ 例全てに free $\mathrm{HBV}$ DNA が, 1 例に integrated HBV-DNAがみつかった と述べている. 本邦の三田村らの報告 ${ }^{10)}$ では，20例の $\mathrm{HBe}$ 抗原陽性 $\mathrm{HBV} キ+リ フ の \zeta ち 17$ 例に free HBV-DNAがみられたが integrated HBV.DNAは 1 例すみられなかった。

我々は, 今回15例の $\mathrm{HBe}$ 抗原陽性慢性肝疾患患者 の肝生検材料 (一部剖検材料) を用い肝内 HBV-DNA の存在様式を検討した結果, 15例中 2 例の進行した高 龄の肝硬変症例に, 肝細胞 DNAへの integrated HBV-DNA が認められた。これら 2 症例は，ともに進 行した肝硬変で，より均一な細胞集団よりなると思わ れる.しかも高龄で, 長年にわたり $\mathrm{HBV}$ 感染が持続し ていたとす考えられる。

肝癌細胞に関する外国及び本邦における多くの報告 は, 腫瘍細胞中に HBV-DNA が極めて高頻度に組み 込まれていることを示している。しかしながら， B型 肝炎感染症において，僈性肝炎から肝硬変，そして肝 癌への過程において, HBV-DNAがいつ, いかにして 肝細胞 DNAに組又込をれ，癌化していくかは明らか でない，今回我々が示した如く，臨床的に広く用いら れている肝生検材料を用いて肝内 HBV-DNA を解析 することは可能であり, 今後 $\mathrm{HBe}$ 抗体陽性者, あるい は非 A非B型といわれる肝疾患での肝内 HBV-DNA の検索は，血清の検索のみからでは得られなかった情 報を与えてくれる可能性がある. 特に今回の我々の検 索に怙いて，HBV 感染症のなかでも高㱓でしかも進 行した肝硬変という，発症の極めて高危険群とも考之 られる 2 症例に組み込まれた HBV-DNAが見られた 事は, 極めて興味深い。

又, 肝生検材料よりえられた肝組蟣抽出 DNA 中に は, 少なくとも 3 種類以上のハンンドが認められ, HBV. DNAの異なる増殖過程を示していると思われた。 Mason ら"1は, アヒルB型肝炎ウイルス (DHBV)の 研究より, Southern blot hybridizationを括こならこ とにより, 肝内 free viral DNAにいくつかのパターン がみられこれらはそれぞれ肝内での異なつた増殖形 態の表現であるとした。我々 ${ }^{12)}$ DHBVの検索にお いて, 同様の 4 種の異なった free viral DNAs がある 
ことを示した。ヒト HBV 感染症に怙いても，肝内 HBV-DNA が episomal 或いは組み迅をれた型であ るか否かだけでなく、これら free viral DNAsの各種 増殖形態の検索も可能と考学られる.

Southern blot法では, 肝細胞 DNAの random sites への HBV-DNA の integration の有無について の解析は困難と思われるが, HBe 抗原陽性慢性肝疾患 患者は, 現在, 抗ウイルス剂等による積極的な治療対 象と考克られており，又，組及込をれた HBV-DNAを 保有する患者には，これら抗ウイルス剤は無効である という考えもあり，HBVの肝内に括ける增殖形態を 検索した上で治療を開始する. 或いは治療効果の判定 を怙こなら事などが今後可能になると考光られる。

謝辞：クローン HBV.DNA を供与下さった Dr. J. Summers (Fox Chase Cancer Center, Philaderphia) k深謝 します. 又, 本研究の一部は, 難治性肝资研究班研究費, ウ イルス肝炎研究財団奖励金, 及び科学研究費 (B) 58480215 によった.

$$
\text { 文献 }
$$

1) Brechot C, Pourcel C, Louise A, et al: Presence of integrated hepatitis $B$ virus DNA sequences in cellular DNA of human hepatocellular carcinoma. Nature 286 : 533-535, 1980

2) Shafritz DA, Kew MC: Identification of integrated hepatis B virus DNA sequences in human hepatocellular carcinomas. Hepatology $1: 1-8,1981$

3）就野興夫, 北川知行, 小池克郎, 他：日本の肝癌症 例に括ける B 型肝资ウイルス DNA の組込み。肝 蔵 $24: 358,1983$

4) Beasley RP: Hepatis B virus as the etiologic agent in hepatocellular carcinomaEpidemiologic considerations. Hepatology 2:
21S-26S, 1982

5) Wahl GM, Stern M, Stark GR: Efficient transfer of large DNA fragments from agarose gels to diazobenzyloxymethlpaper and rapid hybridization by using dextran sulfate. Proc Natl Acad Sci USA 76 : 3683-3687, 1980

6) Rigby PWJ, Dieckmann $M$, Rhodes $C$, et al : Labelling deoxyribonucleic acid to high specific activity in vitro by nick translation with DNA polymerase I. J Mol Biol 113 : 237-251, 1977

7) Brechot $C$, Hadchouel $M$, Scotto $J$, et al: Detection of Hepatitis B Virus DNA in Liver and Serum: A direct appraisal of the chronic carrier state. Lancet (ii) : 765-768, 1981

8) Shafritz DA, Shouval D, Sherman HI, et al: Integration of Hepatitis $B$ virus DNA into the genome of liver cells in chronic liver disease and hepatocellular carcinoma. N Engl J Med 305 : 1067-1073, 1981

9) Kam W, Rall LB, Smuckler EA, et al: Hepatitis $B$ viral DNA in liver and serum of asymptomatic carriers.Proc Natl Acad Sci USA $79: 7522-7526,1982$

10）三田村圭二, 井廻道夫, 松崎靖司, 他：HBe 抗原 陽性 HBVキャリアの肝細胞飞おける HBV DNA の存在様式. 肝缄 $24: 797,1983$

11) Mason WS, Aldrich $C$, Summers $J$, et al: Asymmetric replication of duck hepatitis $B$ virus DNA in liver cells: Free minus-stranded DNA. Proc Natl Acad Sci USA 79 : 3997-4001, 1982

12）横須賀収，小俣政男，今関文夫，他：Southern blothybridization による肝内 Duck Hepatitis B Virus-DNA (DHBV-DNA) の検索. 肝䁍 $24: 676$, 1983 


\title{
Analysis of DNA extracts from liver tissue of patients with $\mathrm{HBe}$ antigen positive chronic liver disease by the technique of southern blot and HBV-DNA hybridization
}

\author{
Fumio ImazeKI, Masao Omata, Osamu Yokosuka, Yoshimi Ito, Katsuo UchiumI, \\ Junko MORI, Yasuhisa MATSUYAMA and Kunio OKUDA*
}

DNA extracts from liver tissue of 15 patients (14 biopsies, 1 autopsy) with $\mathrm{HBeAg}$ positive chronic liver diseases were analyzed by the method of Southern blot and HBV-DNA hybridization. Free HBV-DNA was present in all cases, and there were more than 3 different bands of HBV-DNA on the autoradiogram indicating various replicative free viral forms in the infected hepatocytes. Integrated HBV-DNA was not present at specific sites of the hepatocellular genome in the patients with chronic persistent hepatitis and chronic active hepatitis, but it was found in two elderly patients with advanced cirrhosis.

It is of paticular interest to note that HBV-DNA was integrated into specific sites of the hepatocellular genome in advanced B-viral cirrhosis that is generally considered as the group with a high risk of developing hepatocellular carcinoma.

* 1st Departemnt of medicine, Chiba University School of Medicine (Chiba) 